\title{
PENERAPAN APPLIKASI EDUKASI KOMPUTER UNTUK MENINGKATKAN HAPALAN ABJAD DI TK YAPITA SURABAYA
}

\author{
${ }^{1}$ Lianatus Shofia, ${ }^{2}$ Valentine Aqwarinna Gempita, ${ }^{3}$ Nopitasari, ${ }^{4}$ Muchamad Arif \\ ${ }^{1,2,3}$ Fakultas Keguruan dan Ilmu Pendidikan, Universitas Narotama \\ ${ }^{4}$ Fakultas Ekonomi dan Bisnis, Universitas Narotama \\ 4 muchamad.arif@narotama.ac.id
}

\begin{abstract}
ABSTRAK
Penelitian ini bertujuan untuk mengetahui keefektifitasan applikasi edukasi yang diterapkan di TK Yapita Surabaya. Penulis menggunakan metode deskriptif qualitative. Penulis focus bagaimana menerapkan applikasi edukasi komputer dalam membantu siswa menghapal abjad. Penulis melakukan observasi selama 3x pertemuan. Setiap pertemuan, mereka mendapatkan permainan applikasi edukasi computer yang berbeda namun isi materinya sama. Applikasi tersebut sudah terinstal di setiap computer sekolah yang sudah disesuaikan dengan materi yang diajarkan. Subjek penelitian adalah TK A yang berjumlah 30 siswa. Setiap siswa menggunakan computer yang disediakan di setiap pertemuan selama 30 menit. Hasil penelitian menunjukkan bahwa media pembelajaran melalui program komputer yang bervariasi dalam suatu permainan akan membuat anak-anak semakin bersemangat dan antusias untuk belajar karena tidak membosankan. Namun, bagi anak-anak yang kurang memahami urutan abjad, mereka akan mengalami kesulitan dan kebingungan. Serta, anak yang memiliki fisik motoriknya kurang terlatih akan mengalami kesulitan pada saat menggunakan mouse.
\end{abstract}

Kata Kunci: applikasi computer, abjad, antusias, motorik halus

\begin{abstract}
This study aims to determine the effectiveness of the educational application that is applied in Yapita Kindergarten Surabaya. The author uses descriptive qualitative methods. The author focuses on how to apply computer education applications to help students memorize the alphabet. The author made observations during the $3 \mathrm{x}$ meeting. Each meeting, they get a different computer education application game but the contents of the material are the same. The application has been installed on every school computer that has been adapted to the material being taught. The subject of the research was TK A, amounting to 30 students. Each student uses the computer provided at each meeting for 30 minutes. The results showed that learning media through varied computer programs in a game will make children more excited and enthusiastic to learn because it is not boring. However, for children who do not understand the alphabetical order, they will experience difficulties and confusion. Also, children who have poorly trained physics will experience difficulties when using the mouse.
\end{abstract}

Keywords: : computer application, alphabetical, enthusiastic, soft motoric 


\section{PENDAHULUAN}

Media pembelajaran berbasis ICT yang di terapkan di TK YAPITA dalam pengajaran melalui media komputer. Dengan media tersebut diharapkan dapat tercapainya tujuan yang telah dirumuskan dalam pembelajaran baik tujuan kognitif, afektif atau aspek-aspek perkembangan lainnya, karena media tersebut sangat efektif, menarik, serta dapat menstimulasi pikiran karena membantu anak usia dini dari berpikir abstrak ke berpikir konkret.

Dari penerapan media berbasis ICT ini dapat meningkatkan atau mengembangkan semua aspek perkembangan. Dari aspek kognitif anak-anak dapat mengenal konsep dan mengklasifikasikan serta memecahkan masalah lalu mengkomunikasikan apa yang anak pahami seperti anak mengenal konsep bentuk geometri serta mengklasifikasikan bentukbentuk geometri, mengurutkan angka, mengenal angka dll. Dari aspek fisik motorik, anak dapat melatih motorik halusnya pada waktu menggunakan mouse komputer sehingga jari-jari tangan terkoordinasi.

Dari aspek bahasa pembelajaran berbasis ICT ini dapat menambah kosa kata pada waktu terjadi komunikasi ketika muncul rasa ingin tahu anak sehingga timbul pertanyaan entah ke sesama teman atau pada para pendidik selain itu pembelajaran ini dapat mengenalkan abjad menjadi kata. Dari aspek sosial emosional, anak dapat mengekspresikan emosinya dari permainan yang dia kerjakan selain itu dapat mengolah emosinya pada saat pembelajaran. Dengan media komputer juga dapat mengembangkan sosial anak ketika dia terjadi tanya jawab antar teman, saling memberi semangat dan berbagi tempat dan lain-lain.

Aspek seni, anak-anak dapat menghargai hasil yang di buat dari pembelajaran komputer dan menyukai keindahan atau estetis, dapat memainkan warna-warna dan lain-lain. Aspek NAM, anak ketika masuk ruangan komputer bersikap sopan dan salam serta mematuhi perintah para pendidik, menghargai teman dan saling toleransi antar teman, jujur dalam mengerjakan tugas, disiplin dan lain-lain.

\section{METODE PENELITIAN}

Penelitian ini dilaksanakan di TK YAPITA Surabaya. Sekolah ini terletak di Jl. Keputih III/6 Surabaya. Penelitian ini dilaksanakan selama 3x yakni pada hari selasa 9 April 2019, kamis 11 April 2019, dan selasa 16 April 2019. Subjeknya adalah siswa TK A yang berjumlah 30, 14 siswa laki-laki dan 16 siswa perempuan. Jenis penelitian ini adalah deskriptif kualitati karena metode yang digunakan untuk memecahkan masalah yang sedang dihadapi pada situasi sekarang (Ary: 1985, Azwar: 1999, Sukardi: 2004). Materi yang digunakan adalah mengurutkan abjad. Sumber data yang digunakan adalah kegiatan murid ketika menggunakan applikasi edukasi computer untuk mengurutkan abjad. Sedangkan data yang diambil adalah hasil belajar siswa dengan menggunakan applikasi edukasi computer. Setiap computer di TK Yapita sudah mempunyai applikasi edukasi sendiri di dalamnya. Sehingga para guru tidak perlu menginstal applikasi edukasi sendiri. 


\section{HASIL DAN DISKUSI}

Penelitian ini dilaksanakan selama 3x. Siswa selalu belajar tentang abjad terutama mengurutkan abjad setiap pertemuan. Setiap pertemuan mereka belajar menghapal abjad namun setiap pertemuan mempunyai permainan hapalan abjad yang berbeda di komputer sehingga mereka lebih antusias dalam mengahapal semua abjad. Untuk kegiatan dan hasil penelitian akan dijelaskan seperti di bawah ini.

Pada kegiatan awal, anak-anak biasanya berkumpul. Mereka membuat lingkaran. Kemudian, guru melakukan presensi terlebih dahulu. Selanjutnya, guru menjelaskan materi-materi yang akan dipelajari yakni tentang mengenal abjad. Kemudian, anak-anak diberi buku kerja siswa atau pemberian tugas supaya anak-anak semakin memahami penjelasan yang sudah diterima.

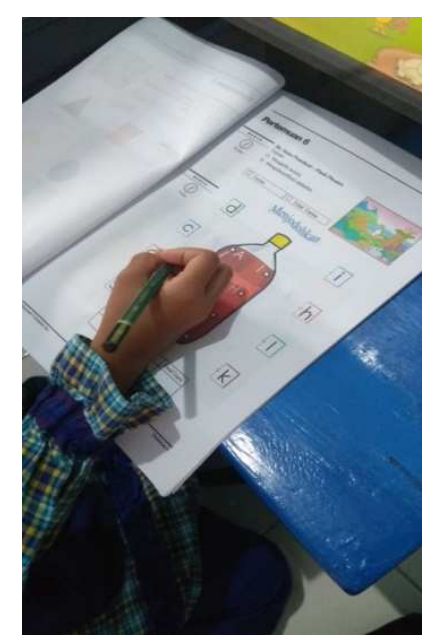

Gambar 1. buku kerja siswa

Selanjutnya pada kegiatan inti, guru mengarahkan anak-anak pada komputer yang sudah disediakan. Kemudian, anak-anak bermain permainan yang sudah tersedia pada program komputer tersebut. Setiap pertemuan, mereka mendapatkan variasi permainan menghapal abjad. Berikut ini adalah salah satu permainan mengurutkan abjad di computer sekolah. 


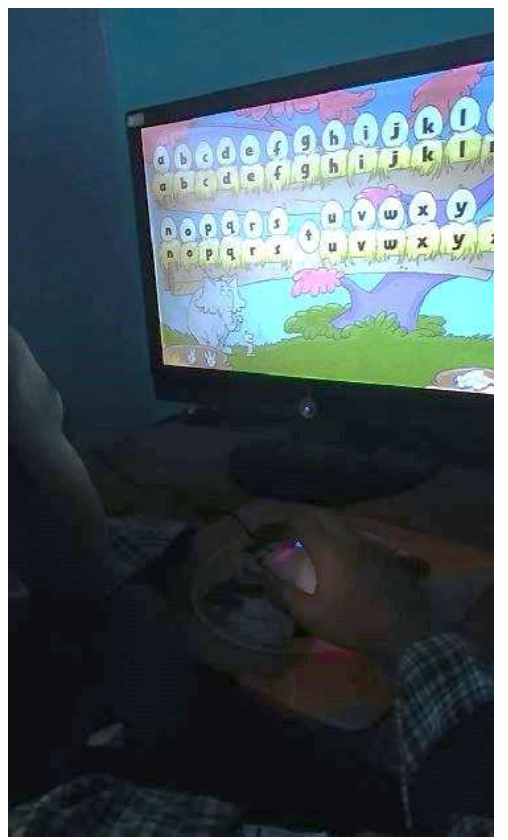

Gambar 2. Permainan mengurutkan abjad

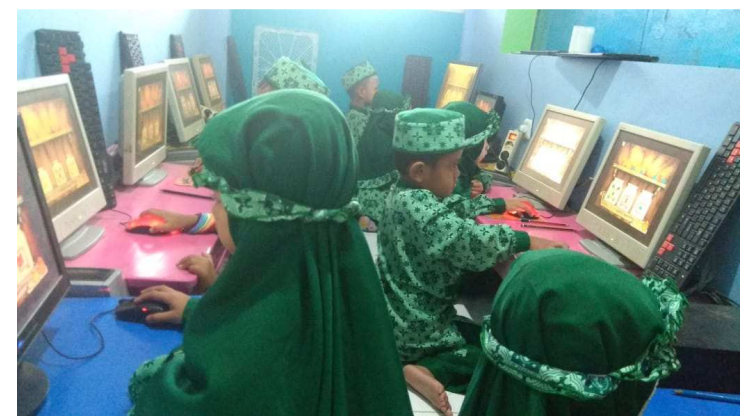

Gambar 3. Siswa mengerjakan permaina mengurutkan abjad

Pada akhir kegiatan, guru biasanya mereview kegiatan pada hari itu. Guru menanyakan perasaan anak-anak setelah melakukan kegiatan pembelajaran tersebut apakah senang, gembira, atau mengalami kesulitan. Serta, guru memberikan motivasi agar anak-anak semakin bersemangat dalam belajar.

Berdasarkan uraian kegiatan di atas, penulis menganalisa kelebihan dan kekurangan penerapan applikasi edukasi computer. Dengan menggunakan media pembelajaran melalui program komputer yang bervariasi dalam suatu permainan, anak-anak semakin bersemangat dan antusias karena tidak membosankan. Selain itu, kegiatan ini dapat mengembangkan semua aspek perkembangan seperti aspek kognitif, sosial emosional, fisik motorik, nilai agama dan moral, seni, serta bahasa. Bahkan, kegiatan ini juga dapat melatih fokus anak.

Dengan menggunakan computer, anak-anak semakin bersemangat dalam belajar serta memunculkan imajinasi anak yang membuat kognitif semakin berkembang. Bahkan, kegiatan ini merupakan hal yang menyenangkan bagi anak-anak. Kegiatan ini juga bisa melatih kepercayaan diri pada anak karena anak dapat menyelesaikan tugasnya secara mandiri dan menghargai keberhasilan yang ia capai. 
Di sisi lain, bagi anak-anak yang kurang memahami abjad atau kurang mengenal urutan abjad akan mengalami kesulitan dan kebingungan. Serta, anak yang fisik motoriknya kurang terlatih akan mengalami kesulitan pada saat menggunakan mouse. Dalam hal ini, guru harus tetap memberikan bimbingan agar dapat memaksimalkan pembelajaran.

\section{KESIMPULAN}

Penerapan pembelajaran berbasis ICT sangat bermanfaat diantaranya membantu anak-anak dalam proses belajar karena pembelajaran berbasis ICT adalah pembelajaran yang menarik dan juga mudah di pahami oleh anak. Bahka, media ini dapat meningkatkan fokus pada anak. Selain itu, pembelajaran berbasis ICT juga dapat meningkatkan perkembangan di semua aspek perkembangan anak, yaitu aspek kognitif, sosial emosional, fisik motorik, nilai agama dan moral, seni, serta bahasa. Di sisi lain, guru juga harus bisa mengembangkan motoric halus anak. Apabila anak mengklik mouse, mereka bisa mengklik dengan sesuai dan benar. Hal ini juga akan berdampak pada kegiatan proses pembelajaran yang lain. 


\section{DAFTAR PUSTAKA}

Ary, Donald. 1985. Introduction to Research In Education. New York:CBS College Publishing Azwar, Saifuddin. 1999. Metode Penelitian. Yogyakarta : Pustaka Pelajar

Sukardi, 2004. Metode Penelitian Pendidikan. Jakarta: Bumi Aksara 